\title{
Polar bears killed in Svalbard 1987-1992
}

\author{
IAN GJERTZ, SISSEL AARVIK and REIDAR HINDRUM
}

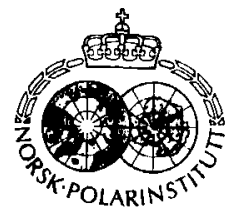

Gjertz, I., Aarvik, S. \& Hindrum, R. 1993: Polar bears killed in Svalbard 1987-1992. Polar Research 12(2). 107-109.

A total of 26 polar bears have been killed in Svalbard since January 1987. Fifteen of these cases were self defense, four precautionary measures, six acts of mercy and one unknown. Twclve of the 15 self defense cases occurred in the wilderness; none occurred in populated arcas. Most self defence cases involved nonresidents of Svalbard and hence people not familiar with polar bear behaviour and encounters.

I. Gjertz. Norsk Polarinstitutt, P.O. Box 505, 9170 Longyearbyen, Norway; S. Aarvik and R. Hindrum, Sysselmannen på Sualbard, 9170 Longyearbyen, Norway.

\section{Introduction}

The implementation of the Agreement on the Conservation of Polar Bears resulted in a total ban on all polar bear hunting in Norwegian territory since 1973 (Anonymous 1974). After July 1973 polar bears have only been shot in acts of self defense, as precautionary measures or in acts of mercy. All such cases are considered as police matters and are either investigated or authorized by the Governor of Svalbard.

Gjertz \& Person (1987) reviewed the recorded information on incidences where polar bears had been killed or had injured people in Svalbard from 1973 to 1987 . A total of 50 such cases had been registered.

The purpose of the present study was to review all known incidents of polar bears killed in Svalbard in the period 1987-1992, including incidents where bears were killed due to conflicts with humans and also those where bears were killed in acts of mercy.

\section{Methods}

In this study the term "serious confrontation" refers to cases where bears have been shot in selfdefense or as a precautionary measure, and to cases where people have been injured or killed by bears.

In addition, bears are sometimes put to death as acts of mercy, for example they have been deemed unable to survive due to old age, injury or disease. This requires special permission from the Governor and occurs primarily when bears take refuge near populated areas and are thus considered a possible threat.

The data on bears killed have been obtained from the Governor's files and the local newspaper, Svalbardposten. The Governor's files consist either of police records or of the conservation officers' records. The latter also contain some biological information on the bears killed. When possible, conservation officers collect data on the sex, age class, zoological length, girth, blubber thickness and weight of the animal. In many cases bears are killed in such remote areas that reports of these incidents reach the Governor too late for the systematic gathering of any biological information.

\section{Results}

A total of 26 polar bears have been reported killed in Svalbard since January 1987 (Table 1). Twelve bears were killed in the summer months of July and August. These same months were the period with most killings in self defense (8). June and November were the only months without any bears being killed.

The geographical distribution of the 26 killing cases (15 self-defense) is as follows: northern coasts of Svalbard, including Nordaustlandet, 9 (8); the eastern coasts of Svalbard, including Edgeøya and Hopen, 8 (6); the western coast of Svalbard 3; and the inner fjord regions of Spitsbergen, 6 (1). Most cases occurring in the fjord areas of Spitsbergen were precautionary measures or acts of mercy. 
Table 1. Polar bears killed in Svalbard 1987-1992.

\begin{tabular}{|c|c|c|c|c|c|c|c|c|c|}
\hline Date & Site & Cause & Involved & Sex & Age-class & Length & $\begin{array}{l}\text { Girth } \\
\text { (cm) }\end{array}$ & Blubber & $\begin{array}{l}\text { Weight } \\
(\mathrm{kg})\end{array}$ \\
\hline 870126 & $80^{\circ} 24^{\prime} \mathrm{N} 26^{\circ} \mathrm{E}$ & $? ?$ & B & & & & & & \\
\hline 870413 & Van Kculenfjorden' & SD & $\mathbf{T}$ & Male & cub & & & & \\
\hline 870727 & Austfonna & SD & $\mathbf{S}$ & & young & & & & \\
\hline 870730 & Austfonna & SD & $\mathbf{S}$ & & young & & & & \\
\hline 870806 & Agardhbukta & SD & $\mathrm{T}$ & Male & subadult & 182 & 135 & & \\
\hline 870815 & Rijpfjorden & SD & $\mathbf{S}$ & Female & adult & 196 & 117 & $>2$ & \\
\hline 870823 & Hopen & PM & $\mathrm{C}$ & Male & adult & 240 & 175 & $>2$ & \\
\hline 870825 & Hopen & $\mathrm{AM}$ & C & Male & adult & 225 & 125 & 0 & \\
\hline 870909 & Kapp Lee, Edgeøya & $\mathrm{SD} / \mathrm{PM}^{2}$ & $\mathrm{~S} / \mathrm{P}$ & Female & cub & 140 & 100 & $0-2$ & \\
\hline 880101 & Mosselbukta & $\mathrm{SD}$ & $\mathrm{L}$ & Malc & adult & & & 0 & \\
\hline 880222 & Rijpfjorden & SD & $\mathrm{T}$ & Malc & adult & & & & \\
\hline 880223 & Isbjørnhamna & AM & $\mathrm{P}$ & Male & adult & 250 & 138 & 0 & \\
\hline 880427 & $80^{\circ} 30^{\prime} \mathrm{N} 8^{\circ} \mathrm{E}$ & $\mathrm{SD}$ & $\mathrm{T}$ & & & & & & \\
\hline 880912 & Krosspynten & SD & $\mathbf{L}$ & Male & adult & & & $0-2$ & ca 200 \\
\hline 881012 & $83^{\circ} \mathrm{N}, \mathrm{NE}$ of Kvit $6 y a$ & PM & $\mathbf{S}$ & Male & subadult & 180 & 114 & $0-2$ & 130 \\
\hline 881227 & Sveagruva & PM & $\mathrm{L}$ & Malc & subadult & 197 & 120 & ()-2 & ca 150 \\
\hline 890802 & Sveagruva & PM & $\mathbf{P}$ & Male & adult & 230 & 145 & $>2$ & 310 \\
\hline 890811 & Sveagruva & $\mathrm{AM}$ & $\mathbf{P}$ & Male & adult & 210 & 135 & $>2$ & ca 150 \\
\hline 900806 & Rijpfjorden & $\mathrm{SD}$ & $\mathrm{T}$ & & & & & & \\
\hline 900726 & Beckerfjellet & SD & $\mathrm{T}$ & Male & subadult & 188 & & $>2$ & \\
\hline 900826 & Agardhbukta & $\mathrm{SD} / \mathrm{AM}$ & $\mathrm{S} / \mathrm{P}$ & Malc & adult & 210 & 117 & $0-2$ & \\
\hline 910730 & Blåfjorddalen & SD & S & Male & subadult & & & & 150 \\
\hline 920323 & Minkinfjellet & AM & $\mathbf{P}$ & Male & adult & & & $>2$ & 340 \\
\hline 920509 & Isbjørnhamna & AM & $\mathbf{P}$ & Malc & adult & 248 & 164 & 0 & \\
\hline 920510 & Kapp Dufferin & $\mathrm{SD}$ & $\mathbf{T}$ & Female & adult & 195 & 114 & $>2$ & \\
\hline 920524 & Isbjørnhamna & AM & $\mathbf{P}$ & Male & adult & 255 & 142 & 0 & \\
\hline
\end{tabular}

I = included in Gjertz \& Persen 1987

$2=$ Human casualty

$\mathrm{SD}=$ self defence $\mathrm{PM}=$ precautionary measure $; \mathrm{AM}=$ act of mercy: ?? = unknown; $\mathrm{B}=$ boat $\mathrm{T}=$ tourist $\mathrm{S}=\mathrm{scientist} ; \mathrm{C}=$ station crew; $L=$ local person; $P=$ police Length = zoological length in $\mathrm{cm}$. Blubber $=$ Thickness in $\mathrm{cm}$ measured along lower back. 0 indicates no blubber present.

No biological data existed on the age of 3 bears killed nor on the sex of 5 bears. Of the 23 bears of known age-class, 14 were adults. Of the 21 bears of known sex, 18 were males. Except for one two-year-old bear in the company of its mother and a sibling (Table 1, 870413), all the bears were believed to have been alone when shot.

\section{Discussion}

The polar bears killed in Svalbard between 1987 and 1992 can be classified according to two main categories, those killed in serious confrontations and those killed for other reasons. Since polar bears are totally protected in Svalbard, incidences falling in the latter category must be authorized by the Governor. Such authorization has hitherto been granted only to policemen and conservation officers. These cases are almost exclusively acts of mercy. It is governmental policy to let old, sick or injured bears die natural deaths unless they take residence close to populated areas. In such cases, to avoid potential serious confrontations and to accommodate public concern for the animals' welfare, these bears may be killed.

According to Larsen (1986) population estimates for polar bears in the Svalbard area nearly doubled from 1967-1970 to 1980-1983, and survival rates increased from the period 1954-1970 to the period 1977-1982. It is therefore probable that the number of bears reaching senility has increased today. No previous review exists of polar bears killed in acts of mercy in Svalbard. We do not know if these cases occur more frequently now than in previous years, but we think this is probable.

Gjertz \& Persen (1987) found that tourists and scientists were involved in 7 out of a total 9 serious 
confrontations that occurred in the months June through August. This was believed to be due to two factors: inexperience with bears and the remoteness of the areas visited. These people often visit the northern and eastern coasts of the archipelago where bears are most common. This trend was found also in the present study. Tourists and scientists were involved in 13 of 15 cases of serious confrontations, all of which occurred in the northern or eastern parts of the archipelago. We believe that many of these incidents could have been avoided had those involved been more experienced with high Arctic conditions.

In the period 1987-1992 only one serious confrontation resulted in human casualty. Human casualties are rare, and apart from the case in 1987, we know of only four cases after 1970 in Svalbard. Three of these were reviewed by Gjertz $\&$ Persen (1987). The fourth case occurred in Bjørnøya in November 1971 (Anonymous 1972).

Basing their estimates on crude information, Gjertz \& Persen (1987) suggested that many bears involved in serious confrontations in Svalbard were young. This same tendency was noted by Stenhouse et al. (1988). In the present study we see the same trend among bears killed in serious confrontations, and these are most often males. This is in agreement with Fleck \& Herrero (1988) who state that subadult males are at least twice as likely to become involved in an aggressive interaction than any other age and sex class. Herrero \& Fleck (1990) found that four of thirteen male bears that attacked humans were thin or skinny, suggesting nutritional stress. The infor- mation of blubber thickness contained in Table 1 is inadequate to determine whether bears killed in self defense are bears that are naturally stressed. As can be expected, blubber measurements (Table 1) show that bears killed in acts of mercy tend to be nutritionally stressed.

Based on the results of this study it seems possible to conclude that those most prone to kill bears in self-defense are inexperienced nonresidents of Svalbard who are visiting the remote northern and eastern areas of Svalbard. The problem bears are predominantly males, often immature.

\section{References}

Anonymous 1972: Tclegrafist på Bjørnøya slått i hjel av isbjørn. Polurboken 1971-1972. P. 154.

Anonymous 1974: Om samtykke til ratifikasjon av avtale av 15 november 1973 om vern av isbjørn i Arktis. Stortingsproposisjon 6 (1974-1975). $15 \mathrm{pp}$.

Fleck, S. \& Herrero, S. H. 1988: Polar bear-human conflicts. Prepared for: Parks Canada, Prairie Region and Department of Renewable Resources. $155 \mathrm{pp}$.

Gjertz, I. \& Persen, E. 1987: Confrontations between humans and polar bears in Svalbard. Polar Research 5, 253-256.

Herrero, S. \& Fleck, S. 1990: Injury to people inflicted by black, grizzly or polar bears: Recent trends and new insights. International Conference on Bear Research and Management $8,25-32$.

Larsen, T. 1986: Population biology of the polar bear (Ursus maritimus) in the Svalbard area. Norsk Polarinst. Skr. 184. $55 \mathrm{pp}$.

Stenhouse, G. B., Lee, L. J. \& Poole K. G. 1988: Some characteristics of polar bears killed during conflicts with humans in the Northwest Territories, 1976-86. Arctic 41. 275-278. 